\title{
Confirmation of the occurrence of a second killer whale morphotype in South African waters
}

\author{
PB Best ${ }^{1 *}$, MA Meÿer ${ }^{2}$, M Thornton ${ }^{1}$, PGH Kotze ${ }^{2}$, SM Seakamela², GJG Hofmeyr ${ }^{3}$, S Wintner $^{4}$, CD Weland $^{5}$ and D Steinke $^{5}$ \\ ${ }^{1}$ Mammal Research Institute, Whale Unit, University of Pretoria, c/o Iziko South African Museum, Cape Town, South Africa \\ 2 Branch: Oceans and Coasts, Department of Environmental Affairs, Cape Town, South Africa \\ ${ }^{3}$ Port Elizabeth Museum at Bayworld, Port Elizabeth, and Department of Zoology, Nelson Mandela Metropolitan University, \\ Port Elizabeth, South Africa \\ ${ }^{4}$ KwaZulu-Natal Sharks Board, Umhlanga Rocks, and Biomedical Resource Unit, University of KwaZulu-Natal, Durban, South Africa \\ ${ }^{5}$ Canadian Centre for DNA Barcoding, Biodiversity Institute of Ontario, University of Guelph, Guelph, Ontario, Canada \\ * Corresponding author, e-mail: pbest@iziko.org.za
}

\begin{abstract}
Killer whales Orcinus orca occur worldwide in a number of morphotypes that differ in size, pigmentation, acoustic behaviour, food type and genetics - some may indeed warrant subspecific or even specific status. Until recently, all killer whales in South African waters were referred to a single morphotype, Type A, but three individuals (two males and one female) that have stranded since 1969 differ in several respects from other killer whales examined from the region. Adult length is some 1-1.5 m smaller, appendages such as dorsal fin and flippers tend to be relatively larger, and tooth wear is excessive. Although dietary information is scant, one stomach contained the remains of several elasmobranchs, identified from a DNA subsample as blue sharks Prionace glauca, a dietary item that, if habitual, might account for the tooth wear. This morphotype, referred to here as 'flat-toothed' and which in several respects resembles the offshore form in the North Pacific and the Type 1 form in the North Atlantic, does not seem to have been previously recorded from the Southern Hemisphere.
\end{abstract}

Keywords: blue shark, dentition, morphometrics, Orcinus orca, prey

Introduction

Killer whales Orcinus orca worldwide tend to occur in distinct morphotypes, variously called types, forms or assemblages. These differ in diet, foraging and acoustic behaviour, morphology and genetics. Three such morphotypes have so far been described in the north-eastern Pacific (resident, transient and offshore assemblages - Ford 2002; Dahlheim et al. 2008), two in the North Atlantic (Type 1 and Type 2 Foote et al. 2009) and four in the Southern Ocean (Type A, Type B and Type C - Pitman and Ensor 2003, and Type D - Pitman et al. 2011). The ranges of these morphotypes can overlap or they may occur sympatrically, and while some are specialist feeders others are more generalist and can feed at different trophic levels. The systematic relationship between these different morphotypes is still not fully resolved, but complete mitochondrial genome analysis suggests that three (North Pacific transients, Southern Ocean Type B and Type $C$ ) could each be elevated to full species and others to subspecies pending additional data (Morin et al. 2010), while Type D could be either a distinct species or subspecies (Foote et al. 2013). The concept of killer whale ecotypes outside the North Pacific has been criticised by De Bruyn et al. (2013) who argue that there has been insufficient long-term behavioural/ecological research to establish whether morphotypes indeed correspond to ecotypes.

Until recently, killer whales occurring in South African waters have been assumed to belong to Type $A$ (Best
2007), but in reviewing the biology of killer whales in South African waters, Best et al. (2010) proposed that a physically mature male, $6.1 \mathrm{~m}$ long with flat teeth, that stranded in 1969 might represent a form distinct from others examined in these waters, and possibly similar to the offshore (North Pacific) or Type 1 (North Atlantic) morphotypes. Those authors also published a late 19th century photograph of a mass stranding of killer whales near Cape Town that seemed to support the occurrence of animals smaller than normal in South African waters. In this paper, we report on additional information (including the examination of a recent stranding of an adult female) that confirms the existence of what we have termed a 'flat-toothed' morphotype in South African waters. Genetic material from these individuals forms part of a wider study of genetic variation in killer whales of the region (Moura et al. 2014).

\section{Material and methods}

The $6.1 \mathrm{~m}$ male that stranded dead at Bordjiesdrif $\left(34^{\circ} 20.47^{\prime} \mathrm{S}, 18^{\circ} 28.42^{\prime} \mathrm{E}\right)$ in the Cape Point Nature Reserve on 4 July 1969 with heavily worn teeth was described and illustrated in Best et al. (2010). No photographs of the whole animal exist, although some film footage was made for Anglia TV (UK) and notes of its colour pattern were taken. Its skull and some post-cranial material are lodged in the 
Iziko South African Museum in Cape Town (catalogue \# ZM 35748).

A $6.05 \mathrm{~m}$ male that stranded at King's Beach, Port Elizabeth $\left(33^{\circ} 58.33^{\prime} \mathrm{S}, 25^{\circ} 38.77^{\prime} \mathrm{E}\right)$, on 8 January 1977 and was described by Ross (1984) also had worn teeth and is included here as a possible example of the flat-toothed type (Figure 1). Two black-and-white press photographs are available from non-standard angles, and the animal was sketched by Ross (1984). Its skull was collected and lodged in the Port Elizabeth Museum (catalogue PEM N0301, previously \#1520/40), and although the rest of the skeleton was buried, no post-cranial material has yet been retrieved.

On 6 October 2010 a 4.78 m female killer whale with worn teeth died shortly after stranding on the beach at Melkbosstrand $\left(33^{\circ} 44^{\prime} \mathrm{S}, 18^{\circ} 26^{\prime} \mathrm{E}\right), 30 \mathrm{~km}$ north of Cape Town (Figure 2). An extensive set of digital images of the animal was taken shortly after death. It appeared to have lost condition, being somewhat emaciated posterior to the dorsal fin: further details of its pathology will not be discussed here. External measurements were taken with a fibreglass tape according to the protocol of Norris (1961). A skin sample for genetics was taken within an hour of death and fixed in $70 \%$ ethyl alcohol. The animal was necropsied and weighed $1339.6 \mathrm{~kg}$ in pieces. During necropsy, the stomachs were removed intact and fixed in $70 \%$ alcohol for later examination. The ovaries were fixed in formalin after weighing and the entire skeleton prepared under maceration. It is now lodged as specimen \# ZM 41853 in the Iziko South African Museum.

The fixed ovaries were sectioned on a manual meat-slicer at a thickness of about $3 \mathrm{~mm}$, the relative abundance of macroscopically visible follicles assessed and the number, size (mean diameter measured on two planes at right angles to each other) and relative age of each corpus albicans recorded as young, medium or old, depending on the relative proportions of pigmentation and scar tissue (Best 1967).

To ascertain the identity of the prey eaten by the Melkbosstrand female, samples of ceratotrichia and two sections of vertebrae were subjected to DNA extraction, after extensive cleaning and crushing to a fine powder, using a validated, criminal forensic, liquid nitrogen, bone DNA extraction protocol. Using specific primer cocktails (AquaF2+C_FishR1t1, AquaF2+C_VR1LRt1, C FishF1t1+C_FishR1t1, and C_VF1LFt1+C_VR1LRt1), the target genetic marker (barcode region of the mitochondrial DNA) was amplified using the polymerase chain reaction $(\mathrm{PCR})$, followed by cycle sequencing with a standardised commercially available BigDye Terminator v. $3.1 \mathrm{kit}$, and subsequently detected by high-voltage capillary electrophoresis on an automated $\mathrm{ABI} 3730 \mathrm{xL}$ DNA Analyzer (Ivanova et al. 2009). DNA sequences recovered from the unknown specimen samples were compared against the species sequence reference library in the Barcode of Life Data System (BOLD) (Ratnasingham and Hebert 2007) accessible at www.boldsystems.org. Bidirectional forward and reverse sequences were generated for each specimen sample. Resulting trace files were assembled into contigs and consensus sequences were then manually edited in CodonCode Aligner (v. 4.1.1) software. Sequences of the mitochondrial DNA COI gene were compared against the reference sequence records available in BOLD (Hebert et

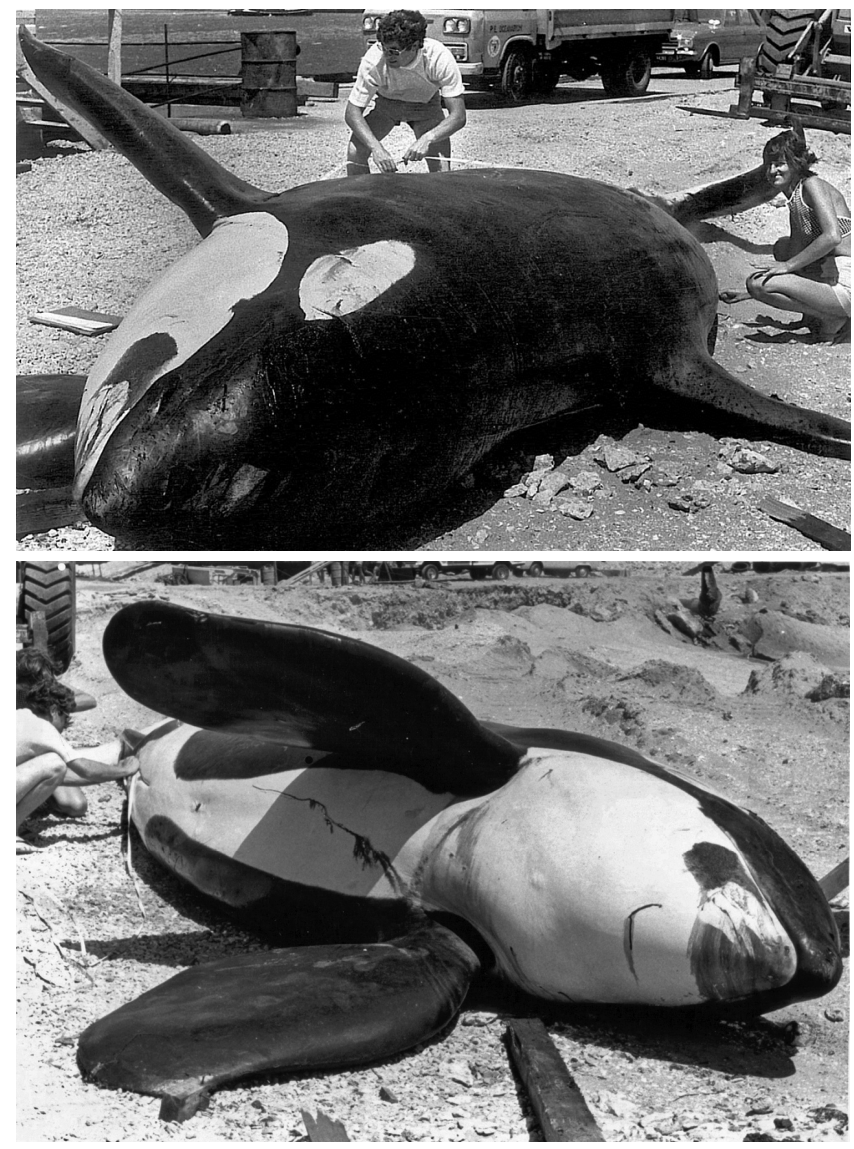

Figure 1: Adult male killer whale stranded at King's Beach, Port Elizabeth, 8 January 1977 (photos: Eastern Province Herald)

al. 2003). Based on a percentage of nucleotide sequence divergence (number of nucleotide substitutions) between a sequence from test sample and a reference DNA barcode, the closest match was used to infer species identity of the DNA contributor in the corresponding test sample.

Skeletal material in the Iziko South African Museum (eight skulls), and the Port Elizabeth Museum (three skulls) was examined, and tooth wear was assessed for each skull (excluding neonates) using a tooth wear (TW) index similar to that developed by Labrada-Martagón et al. (2007):

$$
\mathrm{TW}=\sum \mathrm{q} \times k_{q} / n
$$

where $q$ is the degree of tooth wear, $k_{q}$ is the number of teeth worn to level $q$, and $n$ is the total number of teeth. The degree of wear was assessed as one of four categories: $0=$ no wear, $1=$ wear up to one quarter of crown height, $2=$ wear from one quarter to one half of crown height and 3 = wear more than one half of crown height. In addition, individual teeth collected for age determination from 22 killer whales landed at the Durban $\left(29^{\circ} 53.4^{\prime} \mathrm{S}, 31^{\circ} 03^{\prime} \mathrm{E}\right)$ or Donkergat $\left(33^{\circ} 04.8^{\prime} \mathrm{S}, 18^{\circ} 00^{\prime} \mathrm{E}\right)$ whaling stations and lodged in the Iziko South African Museum were similarly assessed, but as they were presumably chosen for their general lack of wear, they have been effectively treated as a single individual in this analysis to reduce any bias. 


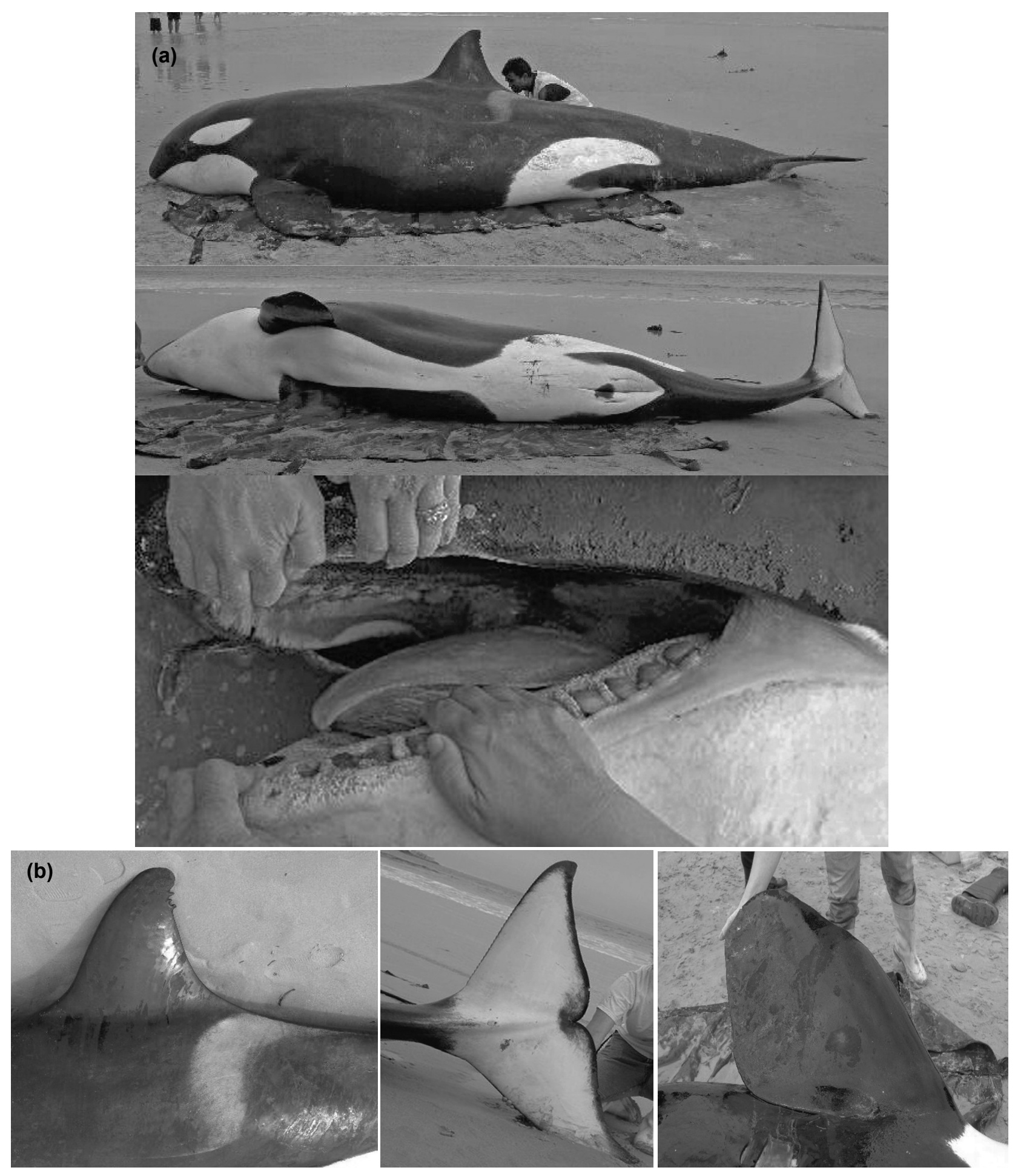

Figure 2: (a) Adult female killer whale stranded at Melkbosstrand, Cape Town, 6 October 2010; (b) views of dorsal fin and saddle, underside of tail, and left flipper of adult female killer whale stranded at Melkbosstrand, Cape Town, 6 October 2010

\section{Results}

\section{Colouration}

The two flat-toothed animals for which images of their external appearance were available seemed little different in overall pigmentation pattern from other killer whales in the region (Figures 1,2). The dorsal grey saddle was closed in the Melkbosstrand female (and illustrated as such for the King's Beach male by Ross 1984), and there was no sign in either animal of the dorsal cape evident in Type B or Type $C$ (Figure $2 b$ ). The slanted or diminutive eye patch as seen in Types $C$ and $D$ respectively was not seen in 
either the Melkbosstrand or King's Beach animal, whereas measurements also indicated a large eye patch for the Bordjiesdrif male (Best et al. 2010).

The eye patch for the Melkbosstrand female seemed smaller than in most local whales, failing to reach as far back as the anterior insertion of the flipper, whereas the white throat marking did not wrap around the anterior insertion of the flipper to the same extent. The orientation of available views of the King's Beach animal was not ideal to evaluate these features, but they did not seem to be inconsistent.

A photograph of a mass stranding of seemingly very small killer whales near Simon's Town in the late 19th century (Best et al. 2010) also portrayed one individual with an eye patch that did not extend as far posteriorly as the flipper insertion. Nevertheless, the sample size is too small, and the colour pattern too variable, for any firm conclusion to be drawn.

\section{Morphometrics}

The total lengths of the two flat-toothed males were $1.5 \mathrm{~m}$ shorter than the modal length of 28 males landed at the Durban and Donkergat whaling stations (Mammal Research Institute Whale Unit data). The Melkbosstrand female was about $2 \mathrm{~m}$ shorter than the modal length of 12 females in the same sample (Figure 3).

The external measurements of the three potential flat-toothed type killer whales from South Africa are listed in Table 1, and the sizes of the appendages compared with those of other killer whales from South African waters (from Best et al. 2010) are shown in Figures 4 and 5.

The sample of flat-toothed animals is very small, but in both sexes the flippers seem relatively longer and wider, and the dorsal fin higher, in flat-toothed animals than in other killer whales of the same length: the data for fluke span are equivocal, with a similar tendency shown for males but not females. Overall, the pattern suggests that the appendages (except possibly the tail flukes) in mature individuals of both forms reach similar sizes relative to body length, but at different body lengths. In effect, the flat-toothed animals are scaled-down versions of the larger form.

Ross (1984) depicts the King's Beach animal as having a forwardly canted dorsal fin, but the available photographic images do not allow confirmation of this. The dorsal fin of the Melkbosstrand female appeared to have a distinctly rounded tip (Figure $2 \mathrm{~b}$ ), a feature recorded as a possible field character for offshore killer whales in the North Pacific (Dahlheim et al. 2008). The flippers of the King's Beach male also had a distinct sigmoid shape to the leading edge (Figure 1, but curiously not shown in the sketch by Ross 1984): such a feature is typical of mature males in (at least) the resident and transient morphotypes in the eastern North Pacific as well as Icelandic killer whales (JKB Ford, University of British Columbia, pers. comm.).

\section{Physical maturity}

Both the Bordjiesdrif male and Melkbosstrand female were classified as physically mature in the field because their anterior thoracic vertebrae were recorded as being fused to the centra. After both specimens were accessioned into the

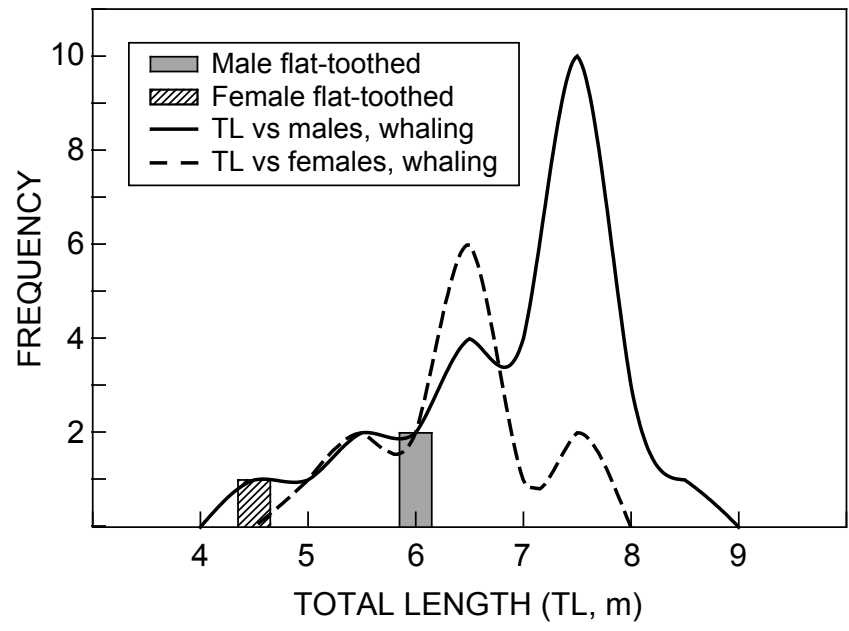

Figure 3: Size composition of killer whales landed at the Durban and Donkergat whaling stations and the lengths of three flat-toothed killer whales stranded on the South African coast

Iziko South African Museum, this diagnosis was confirmed from the male sternum (that was fused into one mass) and the fusion of all epiphyses in the vertebral column of the female. A sectioned tooth from the Bordjiesdrif male also contained 30 dentinal growth layers (Best et al. 2010).

The skeleton of the King's Beach male was not examined in the field and was not accessioned into the Port Elizabeth Museum: the animal was considered sexually maturing and therefore 'probably not very old' (Ross 1984, p 266), but its reproductive status is questioned below. In section, a tooth showed 16 dentinal growth layers with the entire pulp cavity being occluded by nodular, translucent secondary dentine, suggesting that the individual was well past sexual maturity.

\section{Dentition}

Alveolar counts for the three flat-toothed specimens ranged from 11 to 12 for both the maxillary and mandibular toothrows, and for other museum specimens ranged from 11 to 13 for both left and right maxillary tooth rows ( $n=8$, average 12.1 each) and 11 to 12 for both left and right mandibular rows $(n=7$, average 11.4 and 11.7 respectively). Such alveolar counts omitted small rudimentary teeth (found mainly at the anterior end of the tooth rows), because their alveoli were hard to detect if the teeth were absent, the teeth could potentially get lost during preparation, and would almost certainly not be included in counts of erupted teeth in the intact animal.

Tooth wear measurements were available for 11 museum specimens, eight males (condylobasal length [CBL] 91.4-102.2 cm), two females (CBL 87.4-93.8 cm) and one of unknown sex (CBL $101.2 \mathrm{~cm})$. The TW index for the three flat-toothed animals ranged from 2.73 to 3.0 , whereas that calculated for the eight other museum specimens ranged from 0.12 to 1.17 (mean 0.64; SE 0.11). The individual determinations of tooth wear are shown for each specimen in Figure 6.

The TW index for 22 killer whales landed at Durban whaling station between 1971 and 1975 varied between 0 and 1 with an average of 0.5 (Figure 6). Although tooth 
Table 1: External measurements of three flat-toothed killer whales from South Africa

\begin{tabular}{|c|c|c|c|c|c|c|}
\hline \multirow{2}{*}{ Measurement } & \multicolumn{2}{|c|}{ Melkbosstrand female } & \multicolumn{2}{|c|}{ Bordjiesdrif male } & \multicolumn{2}{|c|}{ King's Beach male } \\
\hline & $\mathrm{cm}$ & $\% \mathrm{TL}$ & $\mathrm{cm}^{1}$ & $\% \mathrm{TL}$ & $\mathrm{cm}$ & $\% \mathrm{TL}$ \\
\hline Total length (TL) & 478 & 100 & 609.6 & 100 & 605 & 100 \\
\hline Snout to anus & 332 & 69.5 & 452.1 & 74.2 & 425 & 70.2 \\
\hline Snout to tip of dorsal fin & 241 & 50.4 & 264.2 & 43.3 & 255 & 42.1 \\
\hline Snout to anterior insertion of dorsal fin & 190 & 39.8 & & & 230 & 38.0 \\
\hline Snout to umbilicus & 195 & 40.8 & 259.1 & 42.5 & 260 & 43.0 \\
\hline Snout to angle of gape & 53 & 11.1 & 48.3 & 7.9 & 55 & 9.1 \\
\hline Snout to centre of eye & 54 & 11.3 & 53.3 & 8.7 & 66 & 10.9 \\
\hline Snout to blowhole & 48 & 10.0 & 69.9 & 11.5 & 73 & 12.1 \\
\hline Girth at axilla & 264 & 55.2 & & & 346 & 57.2 \\
\hline Girth, maximum & 286 & 59.8 & 350.5 & 57.5 & 390 & 64.5 \\
\hline Girth at anus & 172 & 36.0 & & & 274 & 45.3 \\
\hline Centre of eye to angle of gape & 8.9 & 1.9 & & & 11 & 1.8 \\
\hline Centre of eye to blowhole & 44.5 & 9.3 & & & 58 & 9.6 \\
\hline Width of blowhole & 9.5 & 2.0 & & & & \\
\hline Length of blowhole & 4.2 & 0.9 & & & & \\
\hline Eye height & 1.1 & 0.2 & & & & \\
\hline Eye length & 4.9 & 1.0 & & & & \\
\hline Length of right mammary slit & 13.4 & 2.8 & & & & \\
\hline Length of left mammary slit & 11.2 & 2.3 & & & & \\
\hline Length of genital opening & 38 & 8.0 & & & 60 & 9.9 \\
\hline Length of anal opening & 12.2 & 2.6 & & & 15 & 2.5 \\
\hline Flipper length anterior insertion to tip, left & 78.4 & 16.4 & $137.2^{*}$ & 22.5 & $135^{*}$ & 22.3 \\
\hline Flipper length anterior insertion to tip, right & 77.2 & 16.2 & & & & \\
\hline Flukes depth of notch & 7.5 & 1.6 & & & 20 & 3.3 \\
\hline
\end{tabular}

* Side unknown

${ }^{1}$ Converted from feet and inches

wear seemed to increase with age, the proportion of individuals with wear in animals aged $\geq 19$ y $(8 / 14)$ was not significantly greater than that in animals aged $\leq 16$ y $(1 / 6$; Fisher exact test, one-tailed $p=0.1192$ ).

\section{Reproduction \\ Female}

The right mammary gland in the Melkbosstrand female was $57 \mathrm{~cm}$ in maximum length, $10.5 \mathrm{~cm}$ wide and $3.1 \mathrm{~cm}$ deep. It was reddish-pink in colour, mature, but with no macroscopic signs of active lactation. The widths of the flattened uterine cornua were $5.8 \mathrm{~cm}$ on the left and $6 \mathrm{~cm}$ on the right, and large, contorted blood vessels were a feature of the sectioned uterine wall. The animal appeared to be a multiparous resting female.

The two ovaries, when fixed, weighed $60 \mathrm{~g}$ (right) and $70 \mathrm{~g}$ (left), and neither contained an active corpus luteum.
These compared with weights of 120-365 g (mean $206.5 \mathrm{~g}$; SE 18.8) for 13 individual ovaries of non-pregnant mature female killer whales landed at South African whaling stations (Best et al. 2010).

The only macroscopically visible follicle (in the right ovary) was $0.45 \mathrm{~cm}$ in diameter, blood-filled and clearly atretic. Ten corpora albicantia in the left ovary and four in the right included no 'young' corpora, seven recorded as 'medium' (1.15-1.65 cm, average $1.4 \mathrm{~cm}$ ) and seven as 'old' $(0.75-1.1 \mathrm{~cm}$, average $0.93 \mathrm{~cm})$ in diameter. The total count of 14 is equivalent to the highest made in 11 mature females examined at the Durban whaling station (Best et al. 2010).

\section{Male}

The testes of the two flat-toothed males were very similar in size, with dimensions (length/diameter) of $48.3 / 16.5 \mathrm{~cm}$ 


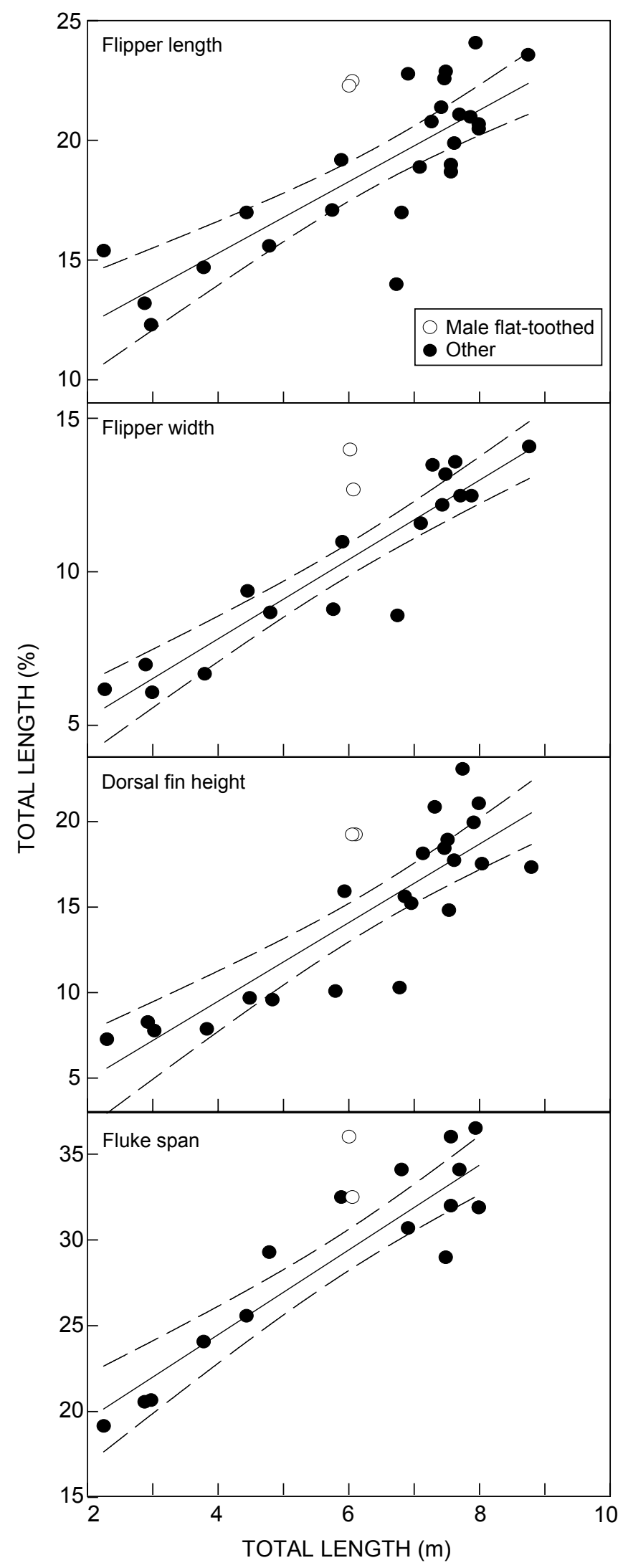

Figure 4: Relative size of the appendages in male flat-toothed and other male killer whales off South Africa. (The 95\% confidence bands for the regressions are shown)

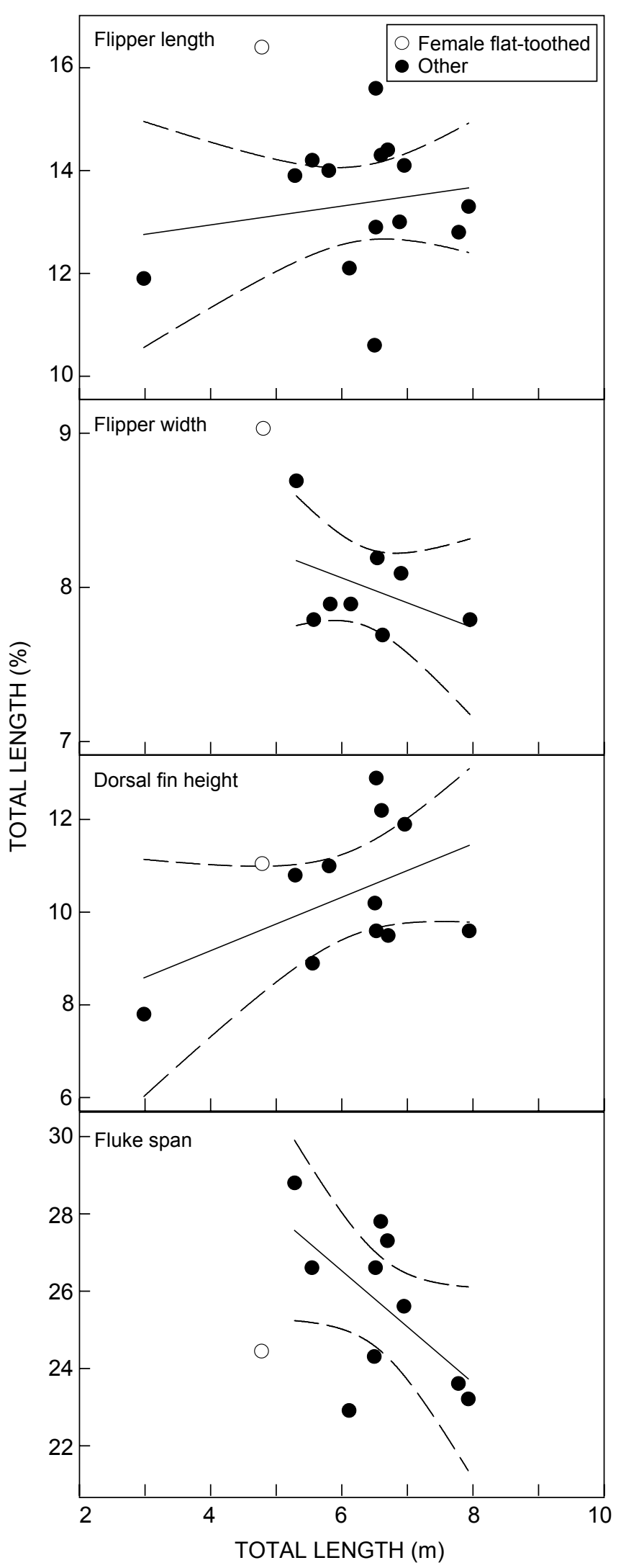

Figure 5: Relative size of the appendages in female flat-toothed and other female killer whales off South Africa. (The 95\% confidence bands for the regressions are shown) 


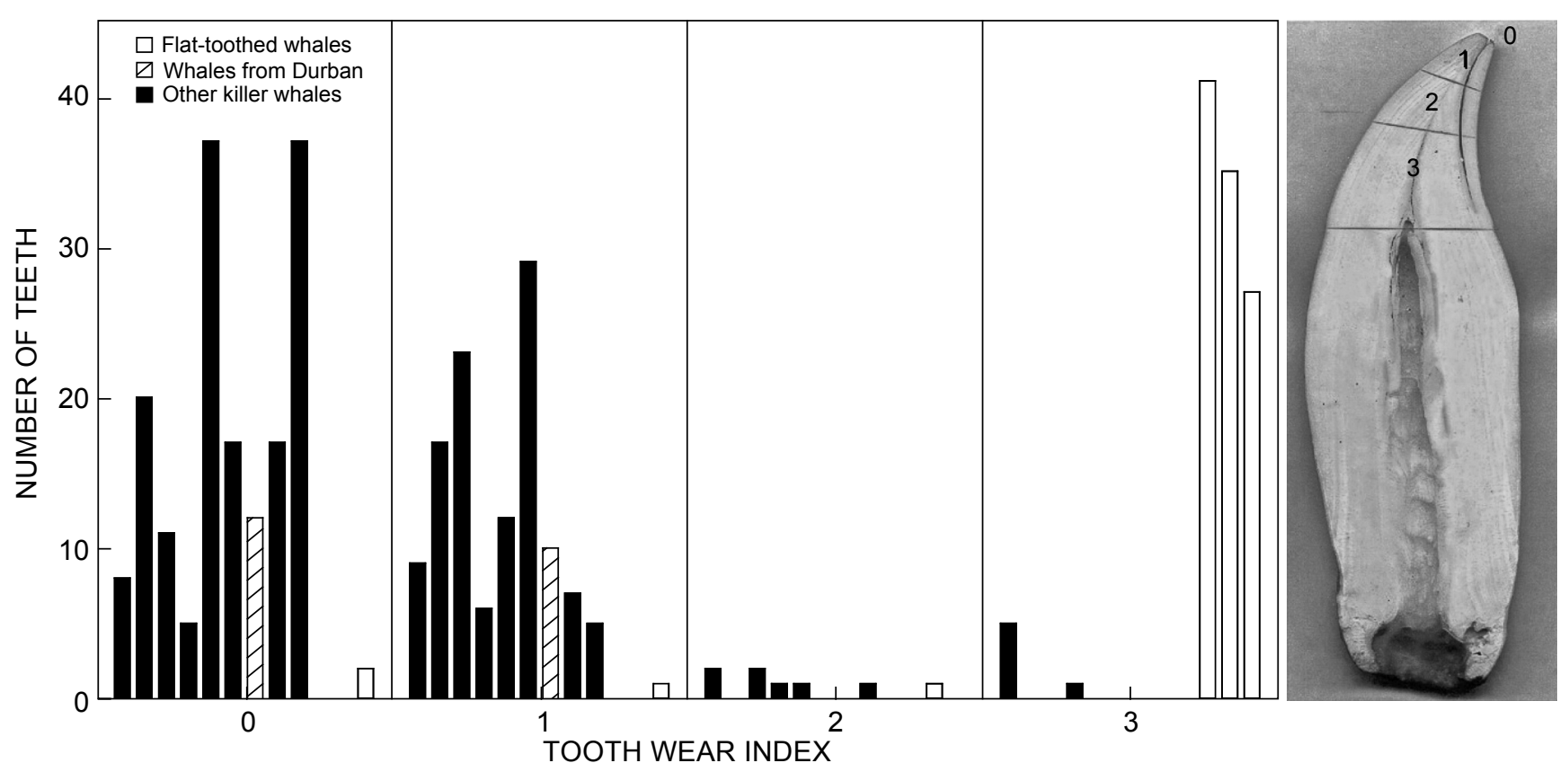

Figure 6: Estimation of tooth wear in individual killer whales from South Africa, showing (right) stages in wear used

and $48.3 / 17.1 \mathrm{~cm}$ for the Bordjiesdrif animal and $49 / 16 \mathrm{~cm}$ (one side only) for the King's Beach animal. Only the single testis of the King's Beach animal was weighed, at $7.2 \mathrm{~kg}$. Despite the size of the testis, Ross (1984) classified the latter specimen as maturing, as the seminiferous tubules, although averaging $170 \mu \mathrm{m}$ in diameter, contained very few spermatozoa, whereas sperm was recorded in the epididymis. The author's conclusion was seemingly reinforced by the testis being intermediate in size between published values for an inactive and mature male killer whale. A sample from the testes of the Bordjiesdrif animal, however, was classified histologically as mature. Given that the scarcity of spermatozoa in the tubules could reflect seasonal fluctuations in spermatogenesis, or even autolysis, the balance of the evidence (testis weight, tubule diameter and enlargement of appendages) would suggest that these were both mature males.

The length of the larger testis in each of these two males was similar to that of other killer whales of similar size examined at South African whaling stations (Figure 7). Larger-testis lengths in eight mature individuals (with a combined testis weight exceeding $6 \mathrm{~kg}$ ) landed at the Durban whaling station ranged from 50 to $101.6 \mathrm{~cm}$, and in seven immature individuals ranged from 5.8 to $41 \mathrm{~cm}$.

\section{Stomach contents}

The stomach contents of the Bordjiesdrif male have already been described (Best et al. 2010) and consisted of $7.5 \mathrm{~kg}$ stalks of kelp Ecklonia sp., a piece of dry suit, a plastic milk bottle, plastic sheeting, a cardboard carton, two albatross Diomedea sp. skins, and two St Joseph (elephant fish) Callorhynchus capensis egg cases. The King's Beach male's stomach was empty.

The contents of the stomachs (combined) of the Melkbosstrand female weighed $10.75 \mathrm{~kg}$, of which $6.795 \mathrm{~kg}$

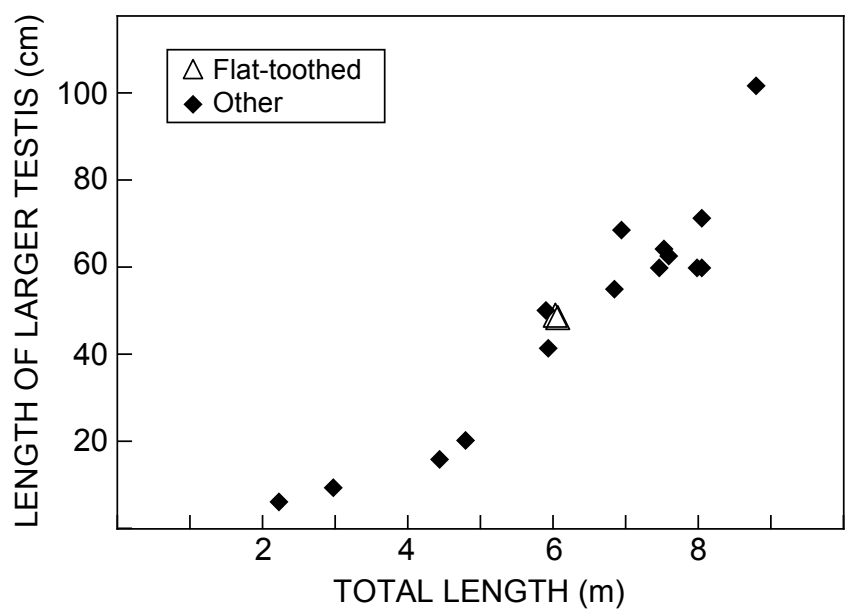

Figure 7: Length of the larger testis in killer whales from South Africa

was in the first compartment. The recognisable remains consisted entirely of fish, comprising 2549 elasmobranch vertebrae, numerous ceratotrichia and one large bony fish vertebra; no skull fragments were detected. The largest elasmobranch vertebrae were identified morphologically as most likely belonging to a carcharhinid shark. Matching DNA barcodes were generated from two vertebral sections and identified as blue shark Prionace glauca. In addition, an Orcinus orca species identification DNA barcode was generated from the ceratotrichia.

Total vertebral counts in the blue shark range from 239 to 252 (Springer and Garrick 1964). Consequently, and assuming all the vertebrae were from blue sharks, the stomach of the Melkbosstrand female contained 
the remains of a minimum of 10-11 individual fish. If the six largest vertebrae (17-18 $\mathrm{mm}$ in diameter, $7.5-9 \mathrm{~mm}$ thickness) were from the region anterior to/below the first dorsal fin, and using an available centrum radius to total length conversion equation for this species in the South Atlantic (Lessa et al. 2004), at least one of the sharks would have been around $2.7-2.85 \mathrm{~m}$ in total length, and the remainder somewhat smaller.

\section{Injury}

The King's Beach male had apparently survived a physical interaction with a $2 \mathrm{~m}$ long swordfish Xiphias gladius, in which a section of the fish's bill had broken off and become lodged in a shallow trough $16 \mathrm{~cm}$ long and $6 \mathrm{~cm}$ wide adjacent to the right mandible (Ross 1984). The circumstances surrounding this interaction are unknown.

\section{Possible sighting}

Although there have been no confirmed sightings of flattoothed killer whales in South African waters (and indeed distinguishing field characters apart from size are not readily apparent), the following sighting event is noteworthy because of the size of the group and its behaviour.

On 27 August 2002, shore-based observers involved in a project monitoring the coastal movements of humpback whales from North Head, Saldanha Bay $\left(33^{\circ} 03^{\prime} \mathrm{S}\right.$, $\left.17^{\circ} 54.7^{\prime} \mathrm{E}\right)$, tracked a group of killer whales by theodolite for 23 minutes before having to abandon their watch because of the lateness of the hour (18:15). Behavioural observations were made through the $22 \times$ telescope sight of the theodolite or using $7 \times 50$ binoculars. At its closest, the group was 3-4 km from the observers, and consisted of 2-3 subgroups spread out over a fairly large area. The total number of individuals was estimated as being up to 20 . There was a lot of tail-slapping by the killer whales and what the observers originally took to be dusky dolphins that were in close association. A footnote to the observation record indicates that, on later reflection, the observers no longer believed these to be dolphins but smaller killer whales.

This instance, plus the apparent mass stranding of at least seven unusually small killer whales near Simon's Town in the late 19th century, suggests that this morphotype may travel in larger social units than other killer whales that tend to be found in groups of six or less in South African waters (Best et al. 2010). Offshore killer whales in the eastern North Pacific also tend to occur in large schools (up to 75-100 animals), frequently exhibit tail-slapping behaviour and have been involved in at least three mass strandings in the region (Dahlheim et al. 2008).

\section{Discussion}

The balance of evidence in this paper confirms the existence of a second morphotype of killer whale in South African waters, differing in size, morphometrics, dental wear, diet and possibly schooling behaviour from the better known, larger form or forms. The distribution, movements and abundance of this morphotype are still largely unknown, but the existing data (and absence of records from a substantial sample from the Durban commercial catch) would suggest that it may be commoner in the South-East Atlantic Ocean than in the South-West Indian Ocean. The scarcity of records would also suggest that it may not be very abundant anywhere in the region. The monthly distribution of the strandings and possible sighting (January, July, October and August respectively) are too few to examine evidence of seasonality.

The flat-toothed form does not conform to any of the previously described morphotypes from the Southern Hemisphere, either in size (Type A), colouration (Types B and $C$ ) or body shape and colouration (Type D). The small size and flat teeth are reminiscent of the offshore type in the North Pacific and Type 1 of the North Atlantic, but, unlike the situation in the North Atlantic, there were no differences detected in the colour pattern nor in the number of mandibular teeth between the flat-toothed and other killer whales in the same ocean basin (Foote et al. 2009).

There is no detailed description of the aetiology of killer whale tooth wear, although in the offshore form from the North Pacific wear seems to begin at an early age, starting in the front teeth and progressing to the back teeth over time (Ford et al. 2011). Caldwell and Brown (1964) speculated that such wear might arise from an undercutting motion of the teeth against each other, but the mechanism for this seems unlikely, and it is now considered more probable that the attrition is diet-related, in particular to the handling of fish with highly abrasive skin such as elasmobranchs (Ford et al. 2011). This hypothesis would seem to be supported by the stomach contents of the flat-toothed female in our study. Nevertheless, such tooth wear in Type 1 killer whales in the North Atlantic has not been linked specifically to their diet, the type being described as a generalist feeder often seen predating on herring and mackerel (Foote et al. 2009). Furthermore, in a population known to forage extensively (but not exclusively) on elasmobranchs off New Zealand (Visser 2005), such excessive tooth wear has never been seen, and most whales have little or no tooth wear (IN Visser, Orca Research Trust, New Zealand, pers. comm.).

However, the degree of wear incurred may depend not only on the nature of the prey but also the species concerned. In most sharks, placoid scales cover the entire body, whereas among rays only sawfish (Pristiformes) and guitarfish (Rajiformes: Rhinobatidae) show a similar body coverage: some members of the Myliobatiformes (including whiptail stingrays and eagle rays) have very few scales or none at all (Meyer and Seegers 2012). Visser (2005) found that over $90 \%$ by number of the elasmobranchs preyed upon by New Zealand killer whales were sting or eagle rays, so although sharks were also taken, their incidence was perhaps not high enough to produce significant tooth wear.

The dental condition of adult individuals of the flat-toothed form raises questions about their ability to forage successfully on larger prey items that may require dismemberment, and how this impairment might impact on their sociality. Observations of carcases recovered after killer whale predation of dolphins (Best et al. 2010), seals (Pitman and Durban 2012) and swordfish (MAM pers. obs.) indicate a very high degree of manipulation amounting to systematic butchering. Even for animals with unworn teeth, such dexterity would be seemingly impossible 
without cooperation in prey-handling between individuals, but animals with worn teeth would seem incapable of participating in any meaningful way in prey dismemberment. Consequently, they must either subsist on smaller prey items or, as proposed by Ford et al. (2011), be provisioned effectively by other school members, as has been previously documented for killer whales (e.g. Hoelzel 1991; Ford and Ellis 2006). Depending on the extent and rapidity with which the tooth wear develops, the burden of provisioning could fall largely on younger members of the school, and this might strengthen and prolong ties between mother and offspring. Energetic costs per individual of such provisioning would be ameliorated if the overall group size was larger.

Has this form of killer whale been recorded elsewhere in the Southern Hemisphere? Unfortunately, there have been insufficient individuals measured to determine whether the New Zealand individuals that feed on elasmobranchs are significantly smaller than other killer whales that occur in the area (IN Visser pers. comm.). One possible candidate is the specimen currently held in the Eden Killer Whale Museum, Eden, New South Wales, Australia, and attributed to 'Old Tom', an adult male well known to local open-boat whalers as one of a group of killer whales that used to participate in hunts for humpback whales (Mead 1962). The teeth of this specimen show strongly asymmetric wear, with the crowns of the fourth upper left, the front six lower left and front two lower right teeth being completely worn off and the seventh lower left having a large anterior groove at the base of the crown, but with the remainder of the teeth being in good condition apart from facets on some crowns caused by occlusion or wear (Mitchell and Baker 1980). This pattern of wear is dissimilar to that shown by shark-eating offshore killer whales in the eastern North Pacific (JKB Ford pers. comm.), although certain common elements (i.e. bilateral asymmetry of wear, greater wear in anterior teeth) have been described (Carl 1946; Caldwell and Brown 1964). The skeleton as displayed measures $6.78 \mathrm{~m}$, but includes several fabricated discs that were inserted between vertebrae when it was mounted in c. 1931 (possibly to make it up to the reported body length of $22 \mathrm{ft}[6.7 \mathrm{~m}])$. In total these discs might amount to as much as $1.34 \mathrm{~m}$ (J White, Eden Killer Whale Museum, New South Wales, Australia, pers. comm.), which if removed would make the adjusted length of the skeleton about $5.44 \mathrm{~m}$. Presumably, in the flesh the animal must have measured closer to $6 \mathrm{~m}$. The dorsal fin and flippers were large, with a reported height and length of $1.73 \mathrm{~m}$ and $1.37 \mathrm{~m}$ (or $25.7 \%$ and $20.5 \%$ of the reported body length) respectively, and the specimen is physically mature, with all vertebral epiphyses fused to their centra (Mitchell and Baker 1980). Although these characteristics (i.e. small adult size, large appendages and advanced tooth wear) are indicative of a flat-toothed animal, the reported behaviour of regularly predating on large whales seems inconsistent with the proposed foraging strategy of the type. However, some doubt remains over the identification of the remains as being those of Old Tom: although identified at the time of death by local people previously familiar with the individual, photographs of its dorsal fin at death do not agree with descriptions or photographs of Old Tom's dorsal fin (Mitchell and Baker 1980; PBB pers. obs.).
As Mitchell and Baker (1980) stated, Old Tom's skeleton represented an adult, socially mature male that barely attained the length of the smallest sexually mature males in the Northern Hemisphere, yet the animal had a dorsal fin nearly as tall as the maximum for any adult bull. Their conclusion, that separate populations of killer whales might differ in length, if not also in the age at sexual maturity, social maturity and asymptotic size, was very prescient, given more recent discoveries. Nevertheless, the information available does not allow an unequivocal assignation of the specimen to a particular morphotype.

Acknowledgements - Dr Len Compagno (Save Our Seas Shark Centre, Kalk Bay, South Africa) and Dr Malcolm Smale (Port Elizabeth Museum at Bayworld, South Africa) kindly attempted morphological identification of the elasmobranch remains from the stomach of the Melkbosstrand female. We are also indebted to $\mathrm{Dr}$ Gavin Gouws (South African Institute for Aquatic Biodiversity) and Dr Sophie von den Heyden (Stellenbosch University, South Africa) for their sterling efforts to facilitate identifying the same stomach contents genetically. Darrel Anders, Steven McCue, Ingrid Peters and André Du Randt assisted with the Melkbosstrand stranding, Graham and Carol Ross were responsible for collecting the King's Beach specimen, and David Cram assisted at the Bordjiesdrif stranding. Jody White (Curator of the Killer Whale Museum, Eden, New South Wales, Australia) kindly provided details relating to Old Tom. Ingrid Visser (Orca Research Trust, New Zealand) was very generous in providing information and images regarding killer whales and their tooth wear in New Zealand. The manuscript was greatly improved by the comments of John Ford (Department of Zoology, University of British Columbia, Canada). PBB acknowledges the support of the National Research Foundation, South Africa.

\section{References}

Best PB. 1967. The sperm whale (Physeter catodon) off the west coast of South Africa. 1. Ovarian changes and their significance. Investigational Report of the Division of Sea Fisheries, South Africa 61: 1-27.

Best PB. 2007. Whales and dolphins of the southern African subregion. Cape Town: Cambridge University Press.

Best PB, Meÿer MA, Lockyer C. 2010. Killer whales in South African waters - a review of their biology. African Journal of Marine Science 32: 171-186.

Caldwell DK, Brown DH. 1964. Tooth wear as a correlate of described feeding behavior by the killer whale, with notes on a captive specimen. Bulletin of the Southern Californian Academy of Sciences 63: 128-140.

Carl GC. 1946. A school of killer whales stranded at Estevan Point, Vancouver Island. Report of the Provincial Museum of Natural History, British Columbia 1945: B21-B28.

Dahlheim ME, Schulman-Janiger A, Black N, Ternullo R, Ellifrit D, Balcomb KC III. 2008. Eastern temperate North Pacific offshore killer whales (Orcinus orca): occurrence, movements, and insights into feeding ecology. Marine Mammal Science 24: 719-729.

De Bruyn PJN, Tosh CA, Terauds A. 2013. Killer whale ecotypes: is there a global model? Biological Reviews 88: 62-80.

Foote AD, Newton J, Piertney SB, Willerslev E, Thomas M, Gilbert P. 2009. Ecological, morphological and genetic divergence of sympatric North Atlantic killer whale populations. Molecular Ecology 18: 5207-5217.

Foote AD, Morin PA, Pitman RL, Ávila-Arcos MC, Durban JW, van Helden A, Sinding MS. 2013. Mitogenomic insights into a recently described and rarely observed killer whale morphotype. Polar Biology 36: 1519-1523. 
Ford JKB. 2002. Killer whale Orcinus orca. In: Perrin WF, Würsig B, Thewissen JGM (eds), Encyclopedia of marine mammals. San Diego: Academic Press. pp 669-676.

Ford JKB, Ellis GM. 2006. Selective foraging by fish-eating killer whales Orcinus orca in British Columbia. Marine Ecology Progress Series 316: 185-199.

Ford JKB, Ellis GM, Matkin CO, Wetklo MH, Barrett-Lennard LG, Withler RE. 2011. Shark predation and tooth wear in a population of northeastern Pacific killer whales. Aquatic Biology 11: 213-224.

Hebert PDN, Cywinska A, Ball SL, de Waard JR. 2003. Biological identifications through DNA barcodes. Proceedings of the Royal Society of London Series B 270: 313-321.

Hoelzel AR. 1991. Killer whale predation on marine mammals at Punta Norte, Argentina: food sharing, provisioning and foraging strategy. Behavioural Ecology and Sociobiology 29: 197-204.

Ivanova NV, Borisenko AV, Hebert PDN. 2009. Express barcodes: racing from specimens to identification. Molecular Ecology Resources 9 (Suppl.): 35-41.

Labrada-Martagón V, Aurioles-Gamboe D, Castro-González MI. 2007. Relation of dental wear to the concentrations of essential minerals in teeth of the California sea lion Zalophus californianus californianus. Biological Trace Element Research 115: 107-126.

Lessa R, Santana FM, Hazin FH. 2004. Age and growth of the blue shark Prionace glauca (Linnaeus, 1758) off northeastern Brazil. Fisheries Research 66: 19-30.

Mead T. 1962. Killers of Eden. The story of the killer whales of Twofold Bay. London: Angus and Robertson.

Meyer W, Seegers U. 2012. Basics of skin structure and function in elasmobranchs: a review. Journal of Fish Biology 80: 1940-1967.

Mitchell E, Baker AN. 1980. Age of reputedly old killer whale, Orcinus orca, 'Old Tom' from Eden, Twofold Bay, Australia. Report of the International Whaling Commission (Special Issue 3): 143-154.

Morin PA, Archer FI, Foote D, Vilstrup J, Allen EE, Wade P, Durban J, Parsons K, Pitman R, Li L, Bouffard P, Nielsen SCA,
Rasmussen M, Willerslev E, Gilbert MTP, Harkins T. 2010. Complete mitochondrial genome phylogeographic analysis of killer whale (Orcinus orca) indicates multiple species. Genome Research 20: 908-916.

Moura A, Janse van Rensburg C, Pilot $M$, Tehrani A, Best $P$, Thornton M, Plön S, de Bruyn N, Worley K, Gibbs R, Dahlheim M, Hoelzel AR. 2014. Killer whale nuclear genome and mtDNA reveals widespread population bottleneck during the last glacial maximum. Molecular Biology and Evolution 31: 1121-1131.

Norris KS. 1961. Standardized methods for measuring and recording data on the smaller cetaceans. Journal of Mammalogy 42: 471-476.

Pitman RL, Ensor P. 2003. Three forms of killer whales (Orcinus orca) in Antarctic waters. Journal of Cetacean Research and Management 5: 131-139.

Pitman RL, Durban JW. 2012. Cooperative hunting behavior, prey selectivity and prey handling by pack ice killer whales (Orcinus orca), type B, in Antarctic Peninsula waters. Marine Mammal Science 28: 16-36.

Pitman RL, Durban JW, Greenfelder M, Guinet C, Jorgensen M, Olson PA, Plana J, Tixier P, Towers JR. 2011. Observations of a distinctive morphotype of killer whale (Orcinus orca), type $D$, from subantarctic waters. Polar Biology 34: 303-306.

Ratnasingham S, Hebert PDN. 2007. BOLD: the Barcode of Life Data System (http://www.barcodinglife.org). Molecular Ecology Notes 7: 355-364.

Ross GJB. 1984. The smaller cetaceans of the south east coast of southern Africa. Annals of the Cape Provincial Museums (Natural History) 15: 173-410.

Springer VG, Garrick JAF. 1964. A survey of vertebral numbers in sharks. Proceedings of the United States National Museum 116: 73-96.

Visser IN. 2005. First observations of feeding on thresher (Alopias vulpinus) and hammerhead (Sphyrna zygaena) sharks by killer whales (Orcinus orca) specializing on elasmobranch prey. Aquatic Mammals 31: 83-88. 